\title{
ANALISIS BUDAYA ORGANISASI DAN KOMITMEN ORGANISASI PADA BEBERAPA BANK SWASTA NASIONAL DI KOTA BANDUNG
}

\author{
Deni Kokon Furkony \\ STIE Dharma Negara \\ denifurkony@gmail.com
}

\begin{abstract}
ABSTRAK
Tujuan penelitian ini untuk menganalisis Budaya Organisasi dan Komitmen Organisasi di Bank Swasta diKota Bandung.

Metode deskriptif dapat diartikan sebagai suatu metode dalam meneliti status sekelompok manusia, suatuj objek, suatu set kondisi, suatu sistem pemikiran, ataupun suatu kelas peristiwa pada masa sekarang, tujuannya untuk membuat deskripsi, gambaran atau lukisan secara sistematis, faktual dan akurat mengenai fakta-fakta, sifat-sifat serta hubungan antar fenomena.

Budaya Organisasi di Bank Swasta Kota Bandung sudah baik dan mendukung meningkatnya Komitmen Organisasi karyawan. Hal ini ditunjukkan dengan hasil perhitungan bobot Budaya Organisasi dan Komitmen Organisasi. Dengan demikian apabila Budaya Organisasi baik maka Komitmen Organisasi pun akan ikut baik, Berdasarkan analisa tentang Komitmen Organisasi dapat dikatakan bahwa pegawai di Bank Swasta Kota Bandung secara keseluruhan memiliki Komitmen Organisasi yang tinggi berdasarkan bobot yang dihasilkan dari kuisioner yang penulis sebarkan.
\end{abstract}

Kata Kunci : Budaya Organisasi dan Komitmen Organisasi

\section{ABSTRACT}

The purpose of this study is to analyze Organizational Culture and Organizational Commitment in Private Banks in Bandung City.

Descriptive method can be interpreted as a method in examining the status of a group of people, an object, a set of conditions, a system of thought, or a class of events at the present time, the purpose is to create a systematic, factual and accurate description, picture or painting of facts, traits and relationships between phenomena.

Organizational Culture in the Bandung Private Bank has been good and supports the increase in employee Organizational Commitment. This is indicated by the results of the calculation of the weight of Organizational Culture and Organizational Commitment. Thus if the Organizational Culture is good then the Organizational Commitment will also be good, Based on an analysis of Organizational Commitment it can be said that employees in the Bandung City Private Bank as a whole have a high Organizational Commitment based on the weight generated from the questionnaire that the authors spread. 
Publisher: LPPM STIE Muhammadiyah Bandung

E-ISSN: 2621-5306 P-ISSN: 2541-5255

Vol. 2 No. 3 September - Desember 2018

.Keywords: Organizational Culture and Organizational Commitment 
Publisher: LPPM STIE Muhammadiyah Bandung

E-ISSN: 2621-5306 P-ISSN: 2541-5255

Vol. 2 No. 3 September - Desember 2018

PENDAHULUAN

Kehidupan organisasi yang kondusif adalah dambaan setiap personil dalam sebuah organisasi, baik yang menduduki jabatan sebagai pimpinan maupun sebagai karyawan. Namun untuk menciptakan suasana organisasi yang kondusif tersebut tidaklah mudah untuk diwujudkan, hal itu mengingat bahwa sikap dan perilaku setiap personil dalam organisasi berbedabeda. Oleh karena itu sudah merupakan hal yang biasa bahwa dalam organisasi terjadi perbedaanperbedan sikap personil organisasi (Muchlas, 2008).

Perkembangan dalam dunia usaha di Indonesia saat ini yang semakin cepat dan pesat berakibat juga pada perubahan budaya. Sehingga organisasi dituntut untuk mempunyai budaya yang membedakan dengan organisasi lain yang sejenis. Percepatan perubahan lingkungan berakibat pada perubahan budaya perusahaan, kesuksesan sebuah organisasi tidak hanya didukung oleh budaya organisasi saja tetapi juga bagaimana organisasi tersebut menumbuhkan komitmen organisasi yang dipahami sebagai ikatan kejiwaan individu terhadap organisasi (Muchlas, 2008).

Organisasi yang baik, tumbuh dan berkembang akan menitikberatkan pada sumber daya manusia (human resources) guna menjalankan fungsinya dengan optimal, khususnya menghadapi dinamika perubahan lingkungan yang terjadi. Dengan demikian kemampuan teknis, teoritis, konseptual, moral dari para pelaku organisasi / perusahaan di semua tingkat (level) pekerjaan amat dibutuhkan Pembahasan budaya organisasi dikalangan bisnis dan akademis diawali dengan penelitian tentang suksesnya dunia bisnis Jepang di tahun 1980-an (Mc Kenna dkk, 2005), sebelum pada akhirnya diikuti oleh keberhasilan perusahaanperusahaan besar lainnya seperti Johnson and Johnson, IBM, Mc Donald's dan General Motors. Mereka dapat memenangkan persaingan melalui perhatian yang besar terhadap budaya bagi perusahaan baik bagi karyawannya, pelanggan maupun pemilik perusahaan secara konsisten O'reilly dalam (Kartingsih,2007), Namun kajian budaya organisasi dalam 


\section{Publisher: LPPM STIE Muhammadiyah Bandung \\ E-ISSN: 2621-5306 P-ISSN: 2541-5255 \\ Vol. 2 No. 3 September - Desember 2018}

artian budaya organisasi telah lama diteliti dari para pakar budaya, sosiologi dan antropologi yang tertarik melihat suksesnya sebuah organisasi perusahaan (Amstrong, 2001). Diantaranya juga pakar manajemen Pascale \& Athas (2001) yang mengadakan komparasi antara perusahaan Jepang dengan perusahaan Amerika, dari mulai berdiri hingga tumbuh berkembang.

Pemahaman terhadap budaya organisasi perlu juga dikaitkan dengan diversitas dan karakteristik dari orientasi kerja para anggota organisasi. Hal ini akan memberikan gambaran tentang tindakan, reaksi maupun keputusan mereka terhadap situasi pekerjaannya masing-masing. Cormick (2000) menegaskan adanya indikasi sikap sebagai suatu kondisi sadar yang lebih menunjukkan tingkat perasaan subyektif seseorang terhadap suatu obyek ( pekerjaan ). Hasilnya adalah penilaian tentang baik buruk obyek tersebut dari sudut pandang tertentu. Ketika perusahaan mulai berorientasi pada pembentukan budaya organisasi, berarti pula meletakkan aspek sumber daya manusia dalam posisi strategis melalui para pimpinan puncak atau manajer untuk mengamankan norma perilaku, nilai-nilai dan keyakinan bersama terhadap perusahaan. Sekaligus menjadi suatu alat yang vital bagi manajemen bila ingin mencapai performance yang tinggi, yang pada akhirnya tercipta sikap kerja yang positif yang mendorong peningkatan kinerja karyawan dan manajemen, diwujudkan dalam seluruh aktifitas dan kebijakan perusahaan.

Di Indonesia pada awalnya budaya organisasi hanya dianggap sebagai pelengkap dalam arti konsep nilai inti (Core Values) yang datang dan dibentuk dari pimpinan saja (Swa, 2004). Namun hadirnya perusahaan-perusahaan multinasional di Indonesia dengan manajemen yang adaptif (sensitive) terhadap budaya local, turut mempengaruhi pandangan umum tentang konsep budaya organisasi. Riset sendiri menunjukkan bahwa budaya merupakan variabel pembeda utama dalam lingkup perusahaan multinasional yang memerlukan para pemimpin atau manajer cosmopolitan (Martin and Owen, 2000). 
Publisher: LPPM STIE Muhammadiyah Bandung

E-ISSN: 2621-5306 P-ISSN: 2541-5255

Vol. 2 No. 3 September - Desember 2018

Melihat dampak budaya organisasi yang begitu besar terhadap suksesnya suatu bisnis serta pentingnya pemeliharaan komitmen karyawan maka penelitian ini dilakukan di Bank Swasta se Kota Bandung.

Bank Swasta se Kota Bandung memiliki potensi SDM dalam kapasitas yang beragam untuk menjalankan berbagai fungsi kegiatan perbankan. Disisi lain perusahaan juga harus menjalankan fungsi social secara internal dan eksternal untuk menjamin kesejahteraan para anggotanya yang juga berdampak pada kelangsungan hidup perusahaan. Terlebih penting menjaga tingkat persaingan diantara industri sejenis baik lokal maupun internasional.

\section{Bank Swasta Se-Kota}

Bandung sebagai perusahaan jasa telah memiliki Visi dan Misi Perusahaan yang menjadi landasan bagi perusahaan untuk menetapkan strategi-strategi bisnis yang akan dijalankan dalam memenangkan persaingan.

Visi Bank Swasta Se-Kota Bandung : “ Menjadi Bank yang terkemuka dalam mengutamakan kepuasan nasabah". Visi ini kemudian dijabarkan kedalam misi perusahaan sebagai berikut :

1. Memberikan pelayanan unggul dalam pembiayaan perumahan dan industri yang terkait, serta menyediakan produk dan jasa perbankan lainnya.

2. Menyiapkan dan mengembangkan sumber daya manusia yang berkualitas dan profesional serta memiliki integritas yang tinggi.

3. Meningkatkan keunggulan kompetitif melalui inovasi berkelanjutan sesuai dengan kebutuhan nasabah.

4. Melaksanakan manajemen perbankan yang sehat sesuai dengan prinsip kehati-hatian dan Good Corporate Governance untuk meningkatkan Shareholder Values.

5. Memperdulikan kepentingan masyarakat dan lingkungannya.

Untuk mewujudkan Visi dan melaksanakan Misi perusahaan diatas, maka segenap jajaran Bank Swasta Se-Kota Bandung diharuskan untuk memiliki nilai-nilai dasar sebagai berikut :

1. Taat dalam melaksanakan dan mengamalkan ajaran agamanya. 
Publisher: LPPM STIE Muhammadiyah Bandung

E-ISSN: 2621-5306 P-ISSN: 2541-5255

Vol. 2 No. 3 September - Desember 2018

2. Selalu berusaha untuk menimba

Pentingnya

dilakukan

ilmu guna meningkatkan

penelitian di perusahaan ini karena pengetahuan dan ketrampilannya demi kemajuan perusahaan.

3. Mengutamakan kerjasama dalam melaksanakan tugas untuk mencapai tujuan perusahaan dengan kinerja baik.

4. Selalu memberikan yang terbaik secara ikhlas bagi perusahaan dan semua stakeholders.

5. Selalu bekerja secara professional yang kompeten dalam bidang tugasnya.

Faktor eksternal yang begitu kuat sangat mempengaruhi perkembangan dan pertumbuhan Bank Swasta se Kota Bandung. Faktor sosial, kondisi ekonomi, perubahan paradigma dalam masyarakat khususnya di dunia usaha, mendorong perusahaan untuk serius menangani masalah SDM, khususnya penerapan budaya organisasi secara intensif. Terlebih dengan perkembangan lingkup usaha, struktur organisasi, penyebaran lokasi, jumlah karyawan, penataaan manajemen, memberikan konsekuensi balik terhadap budaya organisasi. meskipun budaya organisasi di Bank Swasta sudah dirumuskan, tetapi belum pernah dilakukan penelitian apakah budaya organisasi yang sudah ada memiliki keterkaitan dengan komitmen karyawan.

Pengabdian karyawan atau personil perusahaan terhadap perusahaan memberikan sebuah gambaran yang jelas jika kesadaran untuk loyal terhadap perusahaan merupakan sebuah kunci dari komitmen karyawan Bank Swasta Nasional di Kota Bandung dan komitmen menjadi sebuah permasalahan tersendiri bagi manajemen perusahaan. Konsep komitmen perusahaan didasarkan pada premis bahwa individu membentuk suatu keterikatan terhadap perusahaan. Secara historis, Komitmen perusahaan merupakan perspektif yang bersifat keperilakuan dimana komitmen diartikan sebagai perilaku yang konsisten dengan aktivitas. Komitmen merupakan identifikasi dan keterlibatan seseorang yang relatif kuat terhadap perusahaan atau keinginan anggota perusahaan untuk tetap 
Publisher: LPPM STIE Muhammadiyah Bandung

E-ISSN: 2621-5306 P-ISSN: 2541-5255

Vol. 2 No. 3 September - Desember 2018

mempertahankan keanggotaannya

dalam perusahaan dan bersedia berusaha keras bagi pencapaiaan tujuan perusahaan. Sehingga komitmen perusahaan adalah ikatan psikologis karyawan pada perusahaan yang ditandai dengan adanya; Kepercayaan dan penerimaan yang kuat atas tujuan dan nilai-nilai perusahaan; Kemauan untuk mengusahakan tercapainya kepentingan perusahaan; dan Keinginan yang kuat untuk mempertahankan kedudukan sebagai anggota perusahaan mengemukakan adanya tiga bentuk komitmen perusahaan, yaitu komitmen berkesinambungan (continuance commitment), yaitu komitmen yang berhubungan dengan dedikasi anggota dalam melangsungkan kehidupan perusahaan dan menghasilkan orang yang mau berkorban dan berinvestasi pada perusahaan. komitmen terpadu (cohesion commitment), yaitu komitmen anggota terhadap perusahaan sebagai akibat adanya hubungan sosial dengan anggota lain di dalam organisasi. Ini terjadi karena karyawan percaya bahwa norma-norma yang dianut perusahaan merupakan norma-norma yang bermanfaat, dan komitmen terkontrol (control commitment), yaitu komitmen anggota pada norma perusahaan yang memberikan perilaku ke arah yang diinginkannya. Norma-norma yang dimiliki perusahaan sesuai dan mampu memberikan sumbangan terhadap perilaku yang diinginkan.

\section{TINJAUAN LITERATUR DAN HIPOTESIS}

Perusahaan-perusahaan

cenderung lebih berfokus pada strategi-strategi, misalnya pemasaran (memasang target,iklan, event, etc), produksi, keuangan, dan sebagainya. Pada

umumnya, mereka mengabaikan norma-norma, kebiasaan-kebiasaan atau bahkan budaya suatu perusahaan, padahal menurut penulis Budaya Organisasi merupakan hal penting juga selain strategi-strategi yang diungkapkan diatas seperti yang diutarakan oleh para ahli dibawah ini:

$\begin{array}{lr}\text { Budaya yang kuat } & \text { para } \\ \text { memberikan kepada } & \text { para } \\ \text { karyawan pemahaman } & \text { yang } \\ \text { jelas tentang } & \text { cara } \\ \text { penyelesaian } & \text { urusan }\end{array}$


Publisher: LPPM STIE Muhammadiyah Bandung

E-ISSN: 2621-5306 P-ISSN: 2541-5255

Vol. 2 No. 3 September - Desember 2018

disekitar organisasi. Budaya

memberikan stabilitas pada

organisasi. Tetapi,

sebagaimana terbukti bahwa

budaya dapat juga menjadi

hambatan utama terhadap

perubahan. Pada dasarnya

setiap organisasi mempunyai

budaya dan bergantung pada

kekuatannya. Budaya dapat

mempunyai pengaruh yang

bermakna pada sikap dan

perilaku anggota-anggota

organisasi. Budaya itu

berkaitan dengan cara

karyawan mempersepsikan

karakteristik budaya,

bukannya dengan apakah

mereka menyukai budaya itu atau tidak

(Robbins,

2008:719).

Untuk mencapai tujuan tersebut sumber daya manusia memegang peranan yang sangat dominan, karena manusialah yang pada akhirnya menentukan keberhasilan atau kegagalan kebijaksanaan, strategi, maupun langkah-langkah operasional dalam suatu perusahaan.

Bila organisasi ingin berkembang dengan pesat, organisasi harus mempunyai sumber daya manusia yang berkomitmen pada organisasinya oleh sebab itu budaya organisasi yang kuat akan menghasilkan komitmen organisasi yang kuat pula.

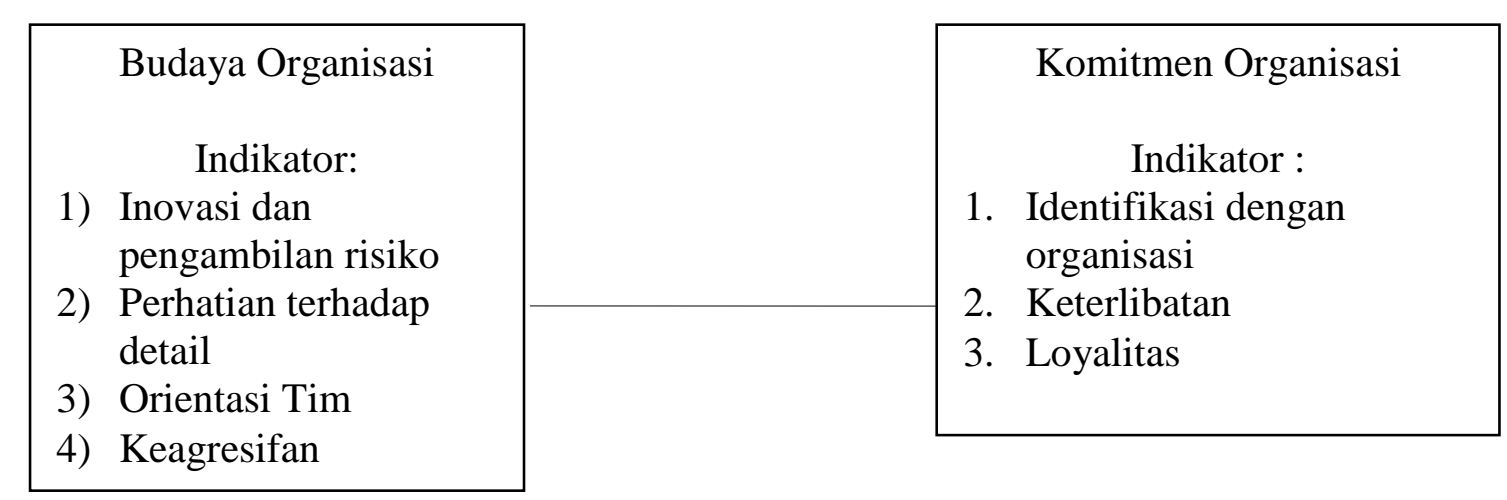

Gambar 1

Paradigma Penelitian 
Publisher: LPPM STIE Muhammadiyah Bandung

E-ISSN: 2621-5306 P-ISSN: 2541-5255

Vol. 2 No. 3 September - Desember 2018

\section{METODE PENELITIAN}

Penelitian ini dilakukan di

Bank Swasta se- Kota Bandung.

Adapun yang menjadi responden

dalam penelitian ini adalah karyawan

Bank Swasta se-Kota Bandung.

Dalam hal ini penulis mencoba

menganalisa Budaya Organisasi dan

Komitmen Organisasi..

Penelitian ini memiliki variabel-variabel yang akan diteliti yang bersifat saling mempengaruhi. Dalam hal ini variabel-variabel ini dapat juga disebut sebagai objek penelitian. Variabel dapat diartikan sebagai sesuatu yang dijadikan objek penelitian sebagai faktor-faktor yang berperan dari peristiwa atau gejala yang akan diteliti. Moch Nazir (2005: 123) mengatakan bahwa variabel adalah konsep yang mempunyai bermacam-macam nilai. Menurut

Sugiyono, (2008:20) mengemukakan bahwa variabel dapat didefinisikan sebagai atribut dari seseorang atau objek yang mempunyai variasi antara satu orang dengan yang lain atau satu objek dengan objek yang lain.

Tabel 1

Operasional Variabel

\begin{tabular}{|c|c|c|c|c|c|}
\hline Variabel & Konseip Variabel & Indikator & Ukuran & Skala & $\begin{array}{c}\text { No } \\
\text { Kuisioner }\end{array}$ \\
\hline \multirow{4}{*}{$\begin{array}{l}\text { Budaya } \\
\text { Organisasi } \\
\text { (X1) }\end{array}$} & \multirow{4}{*}{$\begin{array}{c}\text { Budaya perusahaan } \\
\text { adalah keyakinan } \\
\text { dan nilai bersama } \\
\text { yang memberikan } \\
\text { makna bagi anggota } \\
\text { sebuah institusi dan } \\
\text { menjadikan } \\
\text { keyakinan dan nilai } \\
\text { tersebut sebagai } \\
\text { aturan atau } \\
\text { pedoman } \\
\text { berperilaku di dalam } \\
\text { organisasi Davis } \\
\text { dalam Achmad, } \\
\mathbf{2 0 0 7 : 1 3 1 . ~}\end{array}$} & $\begin{array}{ll}\text { Inovasi dan } \\
\text { pengambilan } \\
\text { risiko }\end{array}$ & $\begin{array}{l}- \text { Tingkat } \\
\text { Inovasi dan } \\
\text { pengambilan } \\
\text { risiko }\end{array}$ & Ordinal & 1,2 \\
\hline & & 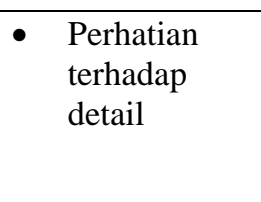 & $\begin{array}{l}\text { - Tingkat } \\
\text { Perhatian } \\
\text { terhadap detail }\end{array}$ & Ordinal & 3 \\
\hline & & - Orientasi tim & $\begin{array}{l}\text { Tingkat Orientasi } \\
\text { Hasil }\end{array}$ & Ordinal & 4 \\
\hline & & - Keagresifan & $\begin{array}{l}\text {-Tingkat } \\
\text { Keagresifan }\end{array}$ & Ordinal & 5 \\
\hline \multirow{3}{*}{$\begin{array}{c}\text { Komitmen } \\
\text { Organisasi } \\
\quad(\mathrm{X} 2)\end{array}$} & \multirow{3}{*}{$\begin{array}{l}\text { Keinginan kuat untuk } \\
\text { tetap sebagai anggota } \\
\text { organisasi tertentu, } \\
\text { Keinginan untuk } \\
\text { berusaha keras sesuai } \\
\text { keinginan organisasi, } \\
\text { Keyakinan tertentu, } \\
\text { dan penerimaan nilai } \\
\text { dan tujuan organisasi }\end{array}$} & $\begin{array}{ll}\text { Identifikasi } \\
\text { dengan } \\
\text { organisasi }\end{array}$ & $\begin{array}{l}\text {-Tingkat } \\
\text { Identifikasi } \\
\text { dengan } \\
\text { organisasi }\end{array}$ & Ordinal & 6 \\
\hline & & - Keterlibatan & $\begin{array}{l}\text {-Tingkat } \\
\text { Keterlibatan }\end{array}$ & Ordinal & 7 \\
\hline & & - Loyalitas & $\begin{array}{l}\text {-Tingkat } \\
\text { Loyalitas }\end{array}$ & Ordinal & 8 \\
\hline
\end{tabular}




\begin{tabular}{|c|c|l|l|l|l|}
\hline & $\begin{array}{c}\text { Luthans } \\
(\mathbf{2 0 0 6 : 2 4 9 )}\end{array}$ & & & \\
\hline
\end{tabular}

Sumber; dari berbagai teori

\section{Teknik Pengumpulan Sampel}

Teknik pengumpulan data untuk mengetahui populasi, perlu terlebih dahulu dikemukakan pengertian yaitu seperti yang dikemukakan oleh Sugiyono (2008:115) bahwa : "Populasi adalah wilayah generalisasi yang terdiri atas: obyek/subyek yang mempunyai kuantitas dan karakteristik tertentu yang ditetapkan oleh peneliti untuk dipelajari dan kemudian ditarik kesimpulannya“.

Teknik Sampling merupakan teknik pengambilan sampel. Terdapat berbagai teknik sampling untuk menentukan sampel yang akan digunakan dalam penelitian, teknik sampling yang digunakan dalam penelitian ini adalah teknik pengambilan Proportiaonate Stratified Random Sampling yaitu teknik pengambilan sampel bila populasi mempunyai anggota/unsur yang tidak homogen dan berstrata proporsional.

Dengan menggunakan formulasi dihitung besarnya unit sampel dari populasi sebesar 422 sebagai berikut:

(Husen

$$
n=\frac{N}{N d 1^{2}+1}
$$

$$
n=\frac{422}{422(0,1)^{2}+1}=81
$$

Jadi, ukuran sampel minimal adalah 81 orang

\section{Teknik Pengumpulan Data}

Teknik pengumpulan data adalah cara yang dipakai dalam mengumpulkan informasi atau keterangan mengenai suatu objek penelitian.

Pelaksanaan pengumpulan data tersebut dapat dilakukan dengan beberapa cara atau alat yang digunakan untuk memperoleh data penelitian yang disebut dengan istilah teknik pengumpulan data. Teknik pengumpulan data yang digunakan dalam penelitian ini adalah sebagai berikut.

1. Observasi

Penulis mengamati secara langsung terhadap objek penelitian untuk mengetahui secara jelas dan nyata tentang

\section{Umar,2008:141)}


Publisher: LPPM STIE Muhammadiyah Bandung

E-ISSN: 2621-5306 P-ISSN: 2541-5255

Vol. 2 No. 3 September - Desember 2018

perusahaan, berhubungan dengan masalah yang diteliti.

2. Wawancara

Wawancara ini dilakukan secara bebas dan terbuka dengan menggunakan pedoman wawancara. Teknik pengumpulan data dilakukan dengan tanya jawab dengan pihak-pihak yang diperkirakan mengetahui seluk beluk objek penelitian dan dapat membantu penulis dalam melengkapi data yang dibutuhkan. Dalam hal ini penulis mewawancarai Kepala Personalia dan beberapa pegawai Bank Swasta se Kota Bandung Bandung. Alat yang dipakai untuk menggunakan teknik wawancara ini ialah pedoman wawancara termasuk dengan daftar pertanyaan yang diajukan.

3. Studi Dokumentasi

Untuk teknik pengumpulan data penunjang digunakan studi dokumentasi. Studi dokumentasi ini bersumber dari dokumen yang dimiliki instansi yang berkaitan dengan permasalahan pengaruh disiplin kerja terhadap produktivitas kerja karyawan.

4. Studi Kepustakaan
Peneliti juga menggunakan studi kepustakaan sebagai penunjang untuk pengajuan hipotesis digunakan beberapa landasan teori yang penulis peroleh melalui kepustakaan (mengumpulkan keteranganketerangan dari berbagai literatur) sebagai bahan perbandingan, acuan atau landasan teoritis yang berkaitan erat dengan masalah yang diteliti yang dilakukan selama penyusunan proposal skripsi.

5. Angket

Teknik pengumpulan data dengan cara menyebarkan pernyataan tertulis yang harus dijawab oleh responden. Setelah itu angket dikumpulkan kembali untuk dianalisis dalam rangka menguji validitas dan reliabilitas angket.

Untuk menilai tanggapan dari setiap responden, penulis menggunakan "Skala Likert", yaitu seluruh pertanyaan yang telah dijawab dihitung bobotnya dan dijumlah seluruhnya agar dapat diketahui nilai setiap responden. Nilai tersebut kemudian akan dijadikan variable penilaian. Bobot jawaban 
Publisher: LPPM STIE Muhammadiyah Bandung

E-ISSN: 2621-5306 P-ISSN: 2541-5255

Vol. 2 No. 3 September - Desember 2018

responden diberi nilai rinci

c.Penerapan sesuai dengan sebagai berikut:

pendekatan penelitian.

Tabel 3

Skor Metode Likert

\begin{tabular}{|c|c|}
\hline Jawaban & $\begin{array}{c}\text { Skor untuk } \\
\text { pernyataan }\end{array}$ \\
\hline Setuju & 3 \\
\hline $\begin{array}{c}\text { Kurang } \\
\text { Setuju }\end{array}$ & 2 \\
\hline Tidak Setuju & 1 \\
\hline \multicolumn{2}{|c|}{ Sumber:data olahan }
\end{tabular}

b. Data Sekunder:

Dalam riset ini penulis membaca literature seperti bukubuku ilmiah, jurnal-jurnal, karya ilmiah dan bahan bacaan yang berhubungan erat dengan sdm pada umumnya dan yang berhubungan dengan Produktivitas Kerjapegawai dan promosi jabatan mereka pada khususnya.

\section{Rancangan Analisis Data}

Data yang berasal dari hasil penelitian dengan menggunakan instrumen angket, studi kepustakaan dan wawancara dianalisis secara kualitatif.

Analisis data hasil penelitian dilakukan melalui langkah-langkah sebagai berikut :

a.Persiapan.

b.Tabulasi. dilakukan melalui langkah-langkah sebagai berikut :

\section{a. Persiapan}

Dalam tahap persiapan ini, kegiatan-kegiatan yang dilakukan adalah

1) Melakukan pengecekan data, identitas dan informasi lainnya yang telah dibutuhkan untuk analisis.

2) Melakukan pemeriksaan seluruh data yang tertuang dalam instrumen penelitian.

3) Memeriksa tata cara pengisian data.

Hasil jawaban dari penyebaran angket dituangkan dalam bentuk tabel-tabel responden, dengan tujuan untuk memudahkan dalam menginterprestasikan dan membahas serta menganalisis hasil penelitian secara operasional. Tanggapan responden meliputi 3 (tiga) alternatif jawaban yaitu untuk alternatif jawaban butir "3" disajikan dengan kata "Setuju", tanggapan untuk alternatif " 2 " disajikan dengan kata "Kurang Setuju “, tanggapan 
Publisher: LPPM STIE Muhammadiyah Bandung

E-ISSN: 2621-5306 P-ISSN: 2541-5255

Vol. 2 No. 3 September - Desember 2018

terhadap alternatif jawaban butir " 1 " disajikan dengan kata "Tidak Setuju ",

Untuk mengetahui nilai dari jawaban responden, digunakan perhitungan pembobotan. Analisis data pada penelitian ini dimulai dengan menganalisis hasil jawaban responden terhadap perubahanperubahan yang dituangkan dalam bentuk tabel-tabel tanggapan responden. Hasil temuan data yang dianalisis terdiri dari data dalam bentuk kata-kata kualitatif dan data dalam bentuk kuantitatif (hasil perhitungan jawaban angket).

Data kualitatif dianalisis menggunakan pendekatan statistik dengan rumus perhitungan sederhana yang penulis gunakan sebagai berikut :

Bobot $=$ Frekuensi $\mathrm{x}$ nilai item pernyataan

Keterangan:

Bobot $=$ Persentase tanggapan responden.

$\mathrm{f}=$ Jumlah responden yang memberikan jawaban atas satu alternatif jawaban. $\mathrm{N}=$ Jumlah seluruh frekwensi anggota sampel yang diamati dan diminta keterangannya

(Sujana 2001:114).

\section{b. Tabulasi data}

Tabulasi data merupakan langkah memasukkan data berdasarkan hasil penggalian data di lapangan. Untuk memperoleh nilai suatu variabel, misalnya nilai $\mathrm{X} 1, \mathrm{X} 2$, atau $\mathrm{X} 3$, bisa langsung data asli dari lapangan dan bisa merupakan hasil penjumlahan dari beberapa poin pertanyaan yang telah dijawab oleh responden.

\section{c. Penerapan sesuai dengan pendekatan penelitian}

Maksudnya hasil dari tabulasi yang berupa angka-angka disesuaikan dengan pendekatan penelitian yang digunakan, dimana pada penelitian ini menggunakan pendekatan kualitatif maka data yang berupa angka-angka dianalisis menjadi kata-kata.

Dengan demikian analisis data yang digunakan dalam penelitian ini menggunakan analisis deskriptif dengan pendekatan kualitatif dengan cara memberikan gambaran-gambaran tentang hasil penelitian tanpa memberikan kesimpulan secara umum tentang 
Vol. 2 No. 3 September - Desember 2018

Disiplin Kerja dan Produktivitas Kerjamelalui penyebaran kuesioner, kemudian diolah dengan cara setiap jawaban yang diberikan diberi nilai (skor) seperti telah dikemukan di atas, skala yang digunakan adalah skala Likert.

\section{Menurut Sugiyono (2008 :}

132) : "Skala Likert digunakan untuk mengatur sikap, pendapat dan persepsi seseorang/sekelompok orang tentang fenomena sosial”.

\section{HASIL DAN DISKUSI}

\section{Analisis Tanggapan Responden}

Untuk

menganalisis tanggapan responden, jawaban responden akan dibobotkan yaitu dengan mengalikan jumlah responden yang menjawab dengan nilai skala likert dari jawaban tersebut. Setelah itu nilai bobot tersebut dibandingkan dengan nilai bobot standar untuk mengetahui Komitmen Organisasinya. Nilai bobot standar ini dibagi ke dalam dibagi ke dalam tiga (3) rentang penilaian yaitu Setujui,kurang setuju, tidak setuju.

Untuk mencari nilai bobot standar dilakukan dengan mencari panjang rentang bobot ketiga pengklasifikasian di atas. Adapun rumusnya sebagai berikut:

$\begin{array}{ll}\frac{\text { Bmaks }- \text { Bmin }_{3}}{3 I} \text { PI } & = \\ \frac{(3 \times 80)-(1 \times 80)}{3} & =\end{array}$

Panjang Rentang $=53$

Keterangan :

PI = panjang interval

Bmaks $=$ bobot jawaban maksimum (3)

Bmin $=$ bobot jawaban minimum (1)

Setelah itu pembobotan dibagi ke dalam tiga (3) tingkatan berdasarkan pengklasifikasian di atas yang dimulai dari 41 Adapun klasifikasi nilai bobot standar yang dihasilkan adalah sebagai berikut :

\section{Tabel 8}

Nilai Bobot Standar

\begin{tabular}{|c|c|}
\hline $\begin{array}{c}\text { Nilai } \\
\text { Bobot }\end{array}$ & $\begin{array}{c}\text { Budaya Organisasi } \\
\text { /Komitmen } \\
\text { Organisasi }\end{array}$ \\
\hline $80-$ & \\
133 & Rendah \\
$134-$ & Sedang \\
187 & Tinggi \\
$188-$ & \\
240 & \\
\hline
\end{tabular}

Dengan membandingkan

nilai bobot jawaban responden 
dengan nilai bobot standar tersebut di atas, maka dapat diketahui mengenai bobot Budaya Organisasi dan Komitmen Organisasi apakah tergolong Tinggi, Sedang, atau Rendah. Hal ini dapat diketahui dengan melihat nilai bobot jawaban berada di golongan yang mana sesuai dengan kategori pada Tabel 8 di atas. Adapun rinciannya sebagai berikut:

\section{Tanggapan Responden Tentang Budaya Organisasi}

Variabel ini terdiri dari 4 item pernyataan yang diambil dari 4 indikator yaitu : Inovasi, Perhatian terhadap detail, Orientasi tim dan Keagresifan, berikut ini adalah hasil pembobotannya:

Tabel 9

Item pernyataan 1

Karyawan didorong agar lebih inovatif

\begin{tabular}{|l|c|c|c|c|}
\hline \multicolumn{1}{|c|}{ Jawaban } & Skor & Frekuensi & Persentase & Bobot \\
\hline Setuju & 3 & 51 & $63,8 \%$ & 153 \\
\hline Kurang setuju & 2 & 24 & $30 \%$ & 48 \\
\hline Tidak setuju & 1 & 5 & $6,3 \%$ & 5 \\
\hline Total & & $\mathbf{8 0}$ & $\mathbf{1 0 0 . 0 0 \%}$ & $\mathbf{2 0 6}$ \\
\hline
\end{tabular}

Sumber: data diolah dari hasil kuesioner

Berdasarkan Tabel 9 di atas dapat kita lihat bahwa item pernyataan karyawan didorong agar lebih inovatif terlihat bahwa persentase responden yang menjawab tidak setuju sebesar $6,3 \%$ dengan bobot 5 sedangkan responden yang menjawab kurang setuju yakni sebesar $30 \%$ dan responden yang menjawab setuju sebesar $63,8 \%$.

Tabel 10

Item pernyataan 2

Karyawan didorong untuk berani mengambil resiko

\begin{tabular}{|l|c|c|c|c|}
\hline \multicolumn{1}{|c|}{ Jawaban } & Skor & Frekuensi & Persentase & Bobot \\
\hline Setuju & 3 & 51 & $63,8 \%$ & 153 \\
\hline Kurang setuju & 2 & 22 & $27,5 \%$ & 44 \\
\hline
\end{tabular}


Publisher: LPPM STIE Muhammadiyah Bandung

E-ISSN: 2621-5306 P-ISSN: 2541-5255

Vol. 2 No. 3 September - Desember 2018

\begin{tabular}{|l|c|c|c|c|}
\hline Tidak setuju & 1 & 7 & $8,8 \%$ & 7 \\
\hline Total & & $\mathbf{8 0}$ & $\mathbf{1 0 0 . 0 0 \%}$ & $\mathbf{2 0 7}$ \\
\hline
\end{tabular}

Sumber: data diolah dari hasil kuesioner

Berdasarkan Tabel 10 di atas

dapat kita lihat bahwa item pernyataan "Karyawan didorong untuk berani mengambil resiko" terlihat bahwa persentase responden yang menjawab tidak setuju sebesar $8,8 \%$ sedangkan responden yang menjawab kurang setuju sebesar $27,5 \%$ dan responden yang menjawab setuju sebesar $63,8 \%$.
Demikian juga jika dilihat berdasarkan nilai bobot yang dihasilkan sebesar 207 Bobot ini berada pada rentang 188-240 dengan kategori tinggi (Tabel 4.6). Artinya pimpinan Bank Swata Kota Bandung mendorong pegawainya agar berani mengambil resiko.

\section{Tabel 11}

Item pernyataan 3

Karyawan diharapkan dapat menggunakan kecermatan dan analisis yang baik.

\begin{tabular}{|l|c|c|c|c|}
\hline \multicolumn{1}{|c|}{ Jawaban } & Skor & Frekuensi & Persentase & Bobot \\
\hline Setuju & 3 & 38 & $47,5 \%$ & 114 \\
\hline Kurang setuju & 2 & 30 & $37,5 \%$ & 60 \\
\hline Tidak setuju & 1 & 12 & $15 \%$ & 12 \\
\hline Total & & $\mathbf{8 0}$ & $\mathbf{1 0 0 . 0 0 \%}$ & $\mathbf{1 8 6}$ \\
\hline
\end{tabular}

Sumber: data diolah dari hasil kuesioner

Berdasarkan Tabel 11 di atas dapat kita lihat bahwa item pernyataan "Karyawan diharapkan dapat menggunakan kecermatan dan analisis yang baik." terlihat bahwa persentase responden yang menjawab tidak setuju sebesar $15 \%$ sedangkan responden yang menjawab kurang setuju sebesar $37,5 \%$ dan responden yang menjawab setuju sebesar 47,5\%. Demikian juga jika dilihat berdasarkan nilai bobot yang dihasilkan sebesar 186 Bobot ini berada pada rentang 134 - 187 dengan kategori sedang (Tabel 4.6). Artinya pimpinan cukup mengharapkan karyawannya menggunakan dan analisis yang baik. 
Tabel 12

Item pernyataan 4

Kegiatan kerja di perusahaan diorganisasikan berdasarkan kerja tim

\begin{tabular}{|l|c|c|c|c|}
\hline \multicolumn{1}{|c|}{ Jawaban } & Skor & Frekuensi & Persentase & Bobot \\
\hline Setuju & 3 & 38 & $47,5 \%$ & 114 \\
\hline Kurang setuju & 2 & 36 & $45 \%$ & 72 \\
\hline Tidak setuju & 1 & 6 & $7,5 \%$ & 6 \\
\hline Total & & $\mathbf{8 0}$ & $\mathbf{1 0 0 . 0 0 \%}$ & $\mathbf{1 9 2}$ \\
\hline
\end{tabular}

Sumber: data diolah dari hasil kuesioner

Berdasarkan Tabel 12 di atas dapat kita lihat bahwa item pernyataan "Kegiatan kerja di perusahaan diorganisasikan berdasarkan kerja tim" terlihat bahwa persentase responden yang menjawab tidak setuju sebesar $7,5 \%$ sedangkan responden yang menjawab kurang setuju sebesar $45 \%$ dan responden yang menjawab setuju sebesar 47,5\%. Demikian juga jika dilihat berdasarkan nilai bobot yang dihasilkan sebesar 192 Bobot ini berada pada rentang 188-240 dengan kategori tinggi (Tabel 4.6). Artinya pimpinan menilai pegawainya sudah mengorganisasikan kegiatan

\section{Tabel 13}

Item pernyataan 5

Karyawan di perusahaan bersikap agresif dan kompetitif dalam bekerja

\begin{tabular}{|c|c|c|c|c|}
\hline \multicolumn{1}{|c|}{ Jawaban } & Skor & Frekuensi & Persentase & Bobot \\
\hline Setuju & 3 & 55 & $68,8 \%$ & 165 \\
\hline Kurang setuju & 2 & 24 & $30 \%$ & 48 \\
\hline Tidak setuju & 1 & 1 & $1,3 \%$ & 1 \\
\hline Total & & 80 & $100 \%$ & 214 \\
\hline Kategori & \multicolumn{5}{|c|}{ Tinggi } \\
\hline
\end{tabular}

Sumber: data diolah dari hasil kuesioner

Berdasarkan tabel 13 di atas, maka ada 68,8\% (55 karyawan) dengan bobot 55 yang setuju "Karyawan di perusahaan bersikap agresif dan kompetitif dalam bekerja,
$30 \% \quad$ (24 karyawan) menjawab kurang setuju dan ada 1 orang atau $1,3 \%$ yang menjawab tidak setuju. Ini berarti sekitar 68,8\% Karyawan di perusahaan bersikap agresif dan 
Publisher: LPPM STIE Muhammadiyah Bandung

E-ISSN: 2621-5306 P-ISSN: 2541-5255

Vol. 2 No. 3 September - Desember 2018

kompetitif dalam bekerja dan ada pada rentang 188-240 atau dalam kategori tinggi, Artinya pegawai Bank Swasta di Kota Bandung bersikap agresif dan kompetitif dalam bekerja menurut penilaian responden dalam hal ini pimpinan Bank Swasta di Kota Bandung

Tabel 14

Total Bobot Budaya Organisasi

\begin{tabular}{|c|c|c|c|}
\hline Variabel Budaya Organisasi & Total Bobot & $\%$ & Kriteria \\
\hline Inovasi dan pengambilan risiko & 206,5 & $23,4 \%$ & Tinggi \\
\hline Perhatian terhadap detail & 186 & $26 \%$ & Sedang \\
\hline Orientasi tim & 192 & $26 \%$ & Tinggi \\
\hline Keagresifan & 214 & $24,6 \%$ & Tinggi \\
\hline Total & 798,5 & $100 \%$ & \\
\hline Rata-rata & 199,6 & & Tinggi \\
\hline
\end{tabular}

Sumber : Data olahan

Berdasarkan tabel 14 di atas, maka rata-rata bobot penilaian responden mengatakan Budaya Organisasi semuanya ada dalam kategori tinggi artinya pegawai Bank Swasta Kota Bandung mempunyai Budaya Organisasi yang tinggi, disini penulis menemukan ternyata bobot yang paling tinggi yaitu keagresifan yang artinya pegawai di Bank Swasta Kota Bandung agresif dalam bekerja sehingga budaya organisasinya tinggi, sedangkan bobot paling rendah yaitu perhatian terhadap detail, dari paparan diatas penulis menyimpulkan bahwa Budaya Organisasi Pegawai Bank Swasta Kota Bandung tinggi atau kuat pernyataan ini sesuai dengan teori

(Robbins, 2007:719) yaitu :

Budaya yang kuat memberikan kepada para karyawan pemahaman yang jelas tentang cara penyelesaian urusan disekitar organisasi. Budaya memberikan stabilitas pada organisasi. Tetapi, sebagaimana terbukti bahwa budaya dapat juga menjadi hambatan utama terhadap perubahan. Pada dasarnya setiap organisasi mempunyai budaya dan bergantung pada kekuatannya. Budaya dapat mempunyai pengaruh yang bermakna pada sikap dan 
Publisher: LPPM STIE Muhammadiyah Bandung

E-ISSN: 2621-5306 P-ISSN: 2541-5255

Vol. 2 No. 3 September - Desember 2018

perilaku anggota-anggota

organisasi. Budaya itu

berkaitan dengan cara

karyawan mempersepsikan

karakteristik budaya,

bukannya dengan apakah

mereka menyukai budaya itu

atau tidak.

\section{Komitmen Organisasi}

Komitmen Organisasi terdiri dari 3 item pertanyaan dengan 3 indikator yaitu : identifikasi dengan organisasi, keterlibatan dan loyalitas. Berikut hasil pembobotannya :

\section{Tanggapan Responden Tentang}

Tabel 15

Item pernyataan 6

Saya merasa senang ikut terlibat dalam perusahaan yang saya tempati

\begin{tabular}{|c|c|c|c|c|}
\hline \multicolumn{1}{|c|}{ Jawaban } & Skor & Frekuensi & Persentase & Bobot \\
\hline Setuju & 3 & 38 & $47,5 \%$ & 114 \\
\hline Kurang setuju & 2 & 34 & $42,5 \%$ & 68 \\
\hline Tidak setuju & 1 & 8 & $10 \%$ & 8 \\
\hline Total & & 80 & $100 \%$ & 190 \\
\hline Kategori & \multicolumn{5}{|c|}{ Tinggi } \\
\hline
\end{tabular}

Sumber: Hasil kuisioner

Berdasarkan tabel 15 di atas, ada $47,5 \%$ (38 karyawan) yang setuju bahwa Pegawai Bank Swasta Kota Bandung merasa senang ikut terlibat dalam perusahaan yang dia tempati, $\quad 42,5 \%$ karyawan) yang kurang setuju, ada $10 \%$ (8 karyawan) tidak setuju, apabila dilihat dari total bobot yang dihasilkan sebesar 190 berada dalam rentang 188-240 hal ini menunjukkan pegawai Bank Swasta Kota Bandung merasa senang ikut terlibat dalam perusahaan yang dia tempati

Tabel 16

Item pernyataan 7

Saya berkeinginan bertahan diperusahaan ini

\begin{tabular}{|c|c|c|c|c|}
\hline Jawaban & Skor & Frekuensi & Persentase & Bobot \\
\hline Setuju & 3 & 32 & $40 \%$ & 96 \\
\hline Kurang setuju & 2 & 42 & $52,5 \%$ & 84 \\
\hline
\end{tabular}


Publisher: LPPM STIE Muhammadiyah Bandung

E-ISSN: 2621-5306 P-ISSN: 2541-5255

Vol. 2 No. 3 September - Desember 2018

\begin{tabular}{|l|c|c|c|c|}
\hline \multicolumn{1}{|c|}{ Tidak setuju } & 1 & 6 & $7,5 \%$ & 6 \\
\hline Total & & 80 & $100 \%$ & 186 \\
\hline Kategori & \multicolumn{5}{|c|}{ Sedang } \\
\hline
\end{tabular}

Sumber: Hasil kuisioner

Berdasarkan tabel 16 di atas, ada $63,4 \%$ setuju jika Pegawai berkeinginan bertahan di Bank Swasta Kota Bandung, 31,7\% kurang setuju dan $4,9 \%$ menjawab tidak setuju jika pegawai Bank Swasta Kota Bandung berkeinginan bertahan diBank Swasta Kota Bandung, apabila dilihat dari total bobot sebesar 186 berada pada rentang 134 - 187 atau kategori sedang jadi sebagian besar pegawai cukup ingin

Tabel 17

Item pernyataan 8

Saya berusaha bekerja keras untuk mencapai tujuan perusahaan

\begin{tabular}{|c|c|c|c|c|}
\hline Jawaban & Skor & Frekuensi & Persentase & Bobot \\
\hline Setuju & 3 & 51 & $63,8 \%$ & 153 \\
\hline Kurang setuju & 2 & 22 & $27,5 \%$ & 44 \\
\hline Tidak setuju & 1 & 7 & $8,8 \%$ & 7 \\
\hline Total & \multicolumn{5}{|c|}{ Tinggi } \\
\hline Kategori & $800 \%$ & 204 \\
\hline
\end{tabular}

Sumber: Hasil kuisioner

Berdasarkan tabel 17 di atas, $63,8 \%$ setuju apabila pegawai berusaha bekerja keras untuk mencapai tujuan perusahaan, $27,5 \%$ kurang setuju dan $8,8 \%$ tidak setuju pegawai Bank Swasta Kota Bandung bertahan di tempat kerja mereka atau Bank di Kota Bandung, Artinya pegawai Bank Swasta Kota Bandung cukup ingin bertahan ditempat kerjanya, untuk yang menjawab tidak setuju karena untuk saat ini biasanya organisasi atau perusahaan banyak yang menarik tenaga kerjanya pegawai kontrak sehingga banyak yang menjawab kurang setuju. 


\begin{tabular}{|c|c|c|c|}
\hline Rata-rata & 193,3 & & Tinggi \\
\hline
\end{tabular}

Sumber: Data Olahan

Berdasarkan tabel 18 di atas, maka rata-rata bobot penilaian responden mengatakan Komitmen Organisasi pegawai Bank Swasta Kota Bandung tinggi, disini penulis menemukan ternyata bobot yang paling tinggi yaitu loyalitas artinya loyalitas pegawai Bank Swasta Kota Bandung tinggi, sedangkan bobot paling rendah yaitu keterlibatan ini menunjukkan pegawai Bank Swasta Kota Bandung belum sepenuhnya terlibat dalam organisasi yaitu Bani Swasta Kota Bandung.

Dari keempat indikator Budaya Organisasi yang paling tinggi nilai bobotnya yaitu Keagresifan dengan total bobot 214, hal ini menunjukkan pegawai Bank Swasta Kota Bandung agresif dalam bekerja sehingga budaya organisasi Bank Swasta di Kota Bandung, sedangkan total bobot yang terendah yaitu Perhatian terhadap detail dengan bobot 186 walaupun masuk dalam ketegori tinggi, hendaknya pimpinan memperhatikan indicator ini karena tidak semua pegawai memperhatikan detail.
Kesimpulan yang dapat ditarik dalam mempertahankan suatu budaya adalah memberikan sebuah penghargaan yang diberikan kepada karyawan atau organisasi yang melakukan pekerjaannya dengan baik dan berhasil berperan terhadap organisasi dalam mensukseskan tujuan dari organisasi, oleh karena itu, budaya harus ditanamkan dengan penuh keyakinan, nilai dan sikap yang baik.

Komitmen Organisasi memiliki bobot rata-rata seb Penelitian ini dilakukan pada karyawan Bank Swasta Kota Bandung. Jumlah responden 41 karyawan, Budaya Organisasi menghasilkan tingkat upaya dan Komitmen Organisasi bawahan melampaui apa yang akan terjadi, bila dilihat dari bobot rata-rata Budaya Organisasi sebesar 199,6 artinya Budaya Organiasi pegawai Bank Swasta Kota Bandung tinggi.

$$
\text { esar 193,3 berada dalam }
$$
kategori tinggi berdasarkan bobot panjang interval, dalam hal ini penulis menemukan ternyata bobot 
Publisher: LPPM STIE Muhammadiyah Bandung

E-ISSN: 2621-5306 P-ISSN: 2541-5255

Vol. 2 No. 3 September - Desember 2018

yang paling tinggi dari ketiga

indicator yang ditentukan penulis

adalah Loyalitas dengan bobot 204

dengan persentase $17,6 \%$ artinya

Pegawai Bank Swasta Kota Bandung

memiliki loyalitas terhadap

perusahaan yang tinggi, sedangkan

bobot yang paling rendah adalah

keterlibatan artinya pegawai belum

sepenuhnya terlibat didalam

organisasi.

Bila organisasi ingin

berkembang dengan pesat, organisasi harus mempunyai sumber daya manusia yang berkomitmen pada organisasinya oleh sebab itu budaya organisasi yang kuat akan menghasilkan komitmen organisasi yang kuat pula.

Berdasarlan paparan diatas

Budaya Organisasi dan Komitmen

Organisasi karyawan Bank Swasta

Kota Bandung sudah sesuai dengan teori dan fenomena yang ada yaitu :

\section{Robbins}

(2007:721)

mengemukakan tujuh karakteristik primer berikut yang, bersamasama, menangkap hakikat dari budaya.

(a) Inovasi dan pengambilan risiko. Sejauh mana para karyawan didorong agar inovatif dan mengambil risiko.

(b) Perhatian terhadap detail. Sejauh mana para karyawan diharapkan memperlihatkan presisi (kecermatan), analisis dan perhatian terhadap detail.

(c) Orientasi hasil. Sejauh mana manajemen memusatkan pehatian pada hasil bukannya pada teknik dan proses yang digunakan untuk mencapai hasil itu.

(d) Orientasi orang. Sejauh mana keputusan manajemen memperhitungkan dampak hasil-hasil pada orang -orang di dalam organisasi itu.

(e) Orientasi tim. Sejauh mana kegiatan kerja diorganisasikan berdasarkan tim, bukannya berdasa individu.

(f) Keagresifan. Sejauh mana orang-orang itu agresif dan kompetitif dan bukannya santai-santai.

(g) Kemantapan. Sejauh mana kegiatan organisasi menekankan dipertahankannya status quo bukannya pertumbuhan. 
Publisher: LPPM STIE Muhammadiyah Bandung

E-ISSN: 2621-5306 P-ISSN: 2541-5255

Vol. 2 No. 3 September - Desember 2018

SIMPULAN

Setelah
pembahasan mengenai masalah
Budaya Organisasi dan Komitmen
Organisasi di Bank Swasta Kota
Bandung, maka dapat ditarik
beberapa kesimpulan antara lain:

1. Budaya Organisasi di Bank Swasta Kota Bandung sudah baik dan mendukung meningkatnya Komitmen Organisasi karyawan. Hal ini ditunjukkan dengan hasil perhitungan bobot Budaya Organisasi dan Komitmen Organisasi. Dengan demikian apabila Budaya Organisasi baik maka Komitmen Organisasi pun akan ikut baik

2. Berdasarkan analisa tentang Komitmen Organisasi dapat dikatakan bahwa pegawai di Bank Swasta Kota Bandung secara keseluruhan memiliki Komitmen Organisasi yang tinggi berdasarkan bobot yang dihasilkan dari kuisioner yang penulis sebarkan.

Ada beberapa saran yang dapat diajukan disini yaitu antara

lain:

1. Budaya Organisasi agar lebih ditingkatkan lagi dengan cara menaikkan bobot indikator yang paling rendah

2. Sebaiknya Komitmen Organisasi ditingkatkan lagi dengan melibatkan seluruh pegawai Bank agar memperhatikan hal yang berkaitan dengan Komitmen Organisasi.

\section{DAFTAR PUSTAKA}

Achmad. 2007. Budaya Organisasi. Yogyakarta: Sekolah Tinggi ilmu manajemen YKPN.

Amstrong. 2008. Hand Book of Personnel Management Practice, Kopan Page Ltd: London

Cormick.2000. Human Factor in Enggineering and Design. Sixth Edition. Mc.Graw-Hill Book Company

Coetzee. 2005. Employee Commitment. [online]. (http://upetd. up.ac.za/thesis/available/etd04132005130646/unrestricted/05chapter 5). Tanggal akses 3 Maret 2007

Djati dan Khusaini .2003. Kajian Terhadap Kepuasan Kompensasi, Komitmen Organisasi, Dan Prestasi Kerja.Jurnal Manajemen \& Kewirausahaan, Vol. 5 No. Universitas Kristen Petra, hal 24-41 
Publisher: LPPM STIE Muhammadiyah Bandung

E-ISSN: 2621-5306 P-ISSN: 2541-5255

Vol. 2 No. 3 September - Desember 2018

Davis dan Newstorm.2005. Perilaku dalam Organisasi (terjemahan: Agus Dharma), Jakarta: Erlangga.

Husen Umar,2008. Desain Penelitian MSDM dan Perilaku

Karyawan .Jakarta : PT Rajagrafindo Persada

Kartingsih.2007. Analisis Pengaruh Budaya Organisasi Dan Keterlibatan Kerja Terhadap Komitmen Organisasi Dalam Meningkatkan Kinerja Karyawan (Studi Pada PT. Bank Tabungan Negara (Persero) Cabang Semarang).Skripsi : Undip.

Luthans.2006. Perilaku Organisasi. Jakarta: Penerbit Andi

Pascale \& Athas.2001. Integrating the Human Resources Function with the Business ", Human Resources Planning, Vol.17. No.2

Martin and Owen.2000. Organizational behavior in education. Boston: Allyn and Bacon

Meyer dan Allen.2001. Commitment Organizations and Occupations: Extension and Test of Three-Component Conceptualization. Journal of Applied Psychol- ogy, vol. 78: 538-551

Mc Kenna.2005. The Essence of Human Resaources Management, Prentice Hall International (UK) Limited Printed and Bound in Great Britain by Tj Press, Padstow, Cornwall

Muchlas. 2008. Perilaku Organisasi. Yogyakarta: Gadjah Mada University Press.
Moh. Nazir. 2005. Metode Penelitian. Jakarta: PT. Ghalia Indonesia

Pabundu Tika.2008. Budaya Organisasi dan Peningkatan Kinerja Perusahaan. Jakarta: Bumi Aksara

Porter, Mowday dan Steers.2001. Employee Organization Linkages: The Psychology of Commitment, Absen teeism and Tumover. New York: Academics Press

Robbins Stephen P, Timothy A. Judge. 2008. Perilaku Organisasi, Edisi 12. Jakarta: Salemba Empat.

Sedarmayanti.2009. Tata Kerja dan Produktivitas Kerja. Bandung: Mandar Maju

Sjafri,2009. Bisnis, Manajemen Sumber Daya Manusia. Bogor: Ghalia Indonesia.

Steers, Richard M.2001. Efektivitas Organisasi : Kaidah Perilaku. Cet. Kedua. Jakarta : Erlangga.

Sopiah.2008.Perilaku Organisasi.Yogyakarta :Andi Offset

Sugiyono. 2008. Metode Penelitian Adminstrasi. Bandung: Alfabeta.

Taliziduhu .2005. Teori Budaya Organisasi. Jakarta: Rineka Cipta

Truckenbrodt.2000. The Relationship Between Leader-Member Exchange and Commitment and Organizational Citizenship Behavior", Journal: Acquisilion Review Quarterly

Welsch dan La Van, 2001. Applied Psychology. New Delhi: McGraw-Hill Publishing, Co. Ltd 
Publisher: LPPM STIE Muhammadiyah Bandung

E-ISSN: 2621-5306 P-ISSN: 2541-5255

Vol. 2 No. 3 September - Desember 2018 